\title{
Status of mangrove research in Latin America and the Caribbean(*)
}

\author{
Yara SCHAEFFER-NOVELLI \& Gilberto CINTRON ${ }^{1}$ \\ Instituto Oceanográfico da Universidade de São Paulo \\ (Caixa Postal 9075, 01051 São Paulo, SP)
}

\begin{abstract}
- Abstract: For those in the eastern hemisphere, the most striking characteristic of New World mangroves must be their low diversity. However, this apparent simplicity is deceptive, New World mangrove species are extraordinarily plastic in their adaptations to their environment. On a geographic basis mangroves attain their greatest development where rainfall and tidal subsidies are abundant. These conditions occur in the northwest part of South American continent and on the eastern seabord, south of the Gulf of Paria (Venezuela) to São Luís, in Brazil. In the 1970's events related to the developing environmental movement in the United States led to a marked interest in these systems, their ecology and management, pointing out the ecological role of mangroves as sources of organic matter to estuarine food webs.The economic recession of the 80 's and its impact on funding agencies, both national and international, and changing national priorities have dramaticaly curtailed scientific research. Research in the region is now almost totally supported by local institutions.The alarming rate at which mangroves are being destroyed in the region requires that prompt action be taken to develop a regional program such as the one recommended in the UNESCO Cali 1978 meeting, capable of fostering and supporting ecosystemic research, the development and compilation of management guidelines and the training of scientific personnel, resource managers, and providing for public environmental education. These guidelines and strategies for effective management of a complex resource can only be developed through research.
\end{abstract}

- Descriptors: Mangrove swamps, Geographical distribution, Historical account, Research programmes, Latin America.

- Descritores: Manguezais, Distribuição geográfica, Avaliação histórica, Programas de pesquisa, América Latina.

\section{Introduction}

From earliest colonial times, mangrove forests captured the attention of New World explorers, settlers and naturalists. Coming from temperate coastal landscapes dominated by herbaceous marshes, they were fascinated by these remarkable trees with the ability to grow in seawater, forming impressive and often impenetrable mazes of aerial roots. They soon discovered that these plants yielded useful products like timber,

(*) Paper presented at the "International Conference on Mangroves", held from December 1 to 5, 1989, in Okinawa, invited by the Japanese Government.

(1) Department of Natural Resources Commonwelth of Puerto Rico, San Juan, P.O.Box 5887 - Puerto Rico.

Contr. no. 719 do Inst. oceanogr. da Usp. firewood and bark for tanning leather. In contrast to the indigenous populations that had lived, fished and made use of these forests for millenia without drastic alterations, New World settlers initiated dramatic changes that ultimately have led to the depletion or degradation of the resource. In fact, as early as 1760, the cutting of mangroves for fuel wood in some provinces of colonial Brazil had reached such proportions that it had become difficult to obtain bark for tannins, causing its price to rise sharply. As a result, the King of Portugal, Dn. Jose, had to issue a proclamation ordering that only debarked trees could be used as fuelwood. Violators faced fines and incarceration.

Unfortunately, in spite of this early rudimentary attempt to manage for multiple uses, New World mangrove resources have not been historically regarded as valuable or important. In fact, they have been and are unfortunately still considered obstacles to economic development or as lands suitable for reclamation. The 
only perceived value is often their real estate value (after filling), especially in highly prized coastal areas.

In this paper we will give a brief overview of some characteristics of New World mangroves and their environment, specifically those related to their management, and will review some of the efforts that have been made in Latin America to foster regional research.

\section{New World mangroves and their environment}

For those in the eastern hemisphere, the most striking characteristic of New World mangroves must be their low species reachness. Old World areas have a very large number of species (more than 40) when compared to the species poor New World mangroves (less than 10). Although these numbers may change depending upon which species are considered "true" mangroves or "major species", certainly this difference is of great interest because of its many implications for research and management. However, this apparent simplicity is deceptive, since mangrove species are extraordinarily malleable in their adaptations to their environment. In fact, the varied responses of these few species to local patterns of tidal and terrestrial drainage influence led Lugo \& Snedaker (1974) to develop a classification system based on the observation that where mangrove stands share similar environmental conditions they attain similar levels of structural development and function. This accomodation to local conditions results in a high diversity of forest types in spite of their floristic simplicity, because of the diversity in growing conditions over their geographic range. Even in a given area, microtopographic features may be reflected in changes in plant structure.

On a geographic basis New World mangroves attain their greatest development where rainfall and tidal subsidies are large. They develop best in equatorial areas influenced by the intense convective activity within the Intertropical Convergence Zone and subjected to mesotidal or macrotidal regimes (mesotidal 2-4 m, macrotidal > $4 \mathrm{~m}$; Davies, 1964). These conditions (annual rainfall $>2000 \mathrm{~mm}$, tidal amplitudes $>2 \mathrm{~m}$ ) occur in the northwest part of the South American continent (northern Ecuador, Pacific coast of Colombia and southern Panama) and on the eastern seabord of the continent south of the Gulf of Paria (Venezuela) to São Luís in Brazil. It is in this moist and dynamic region where the greatest mangrove development occurs. Red mangrove (Rhizophora) forests attaining $40-50 \mathrm{~m}$ in height and more than 1 meter in diameter have been reported in northern Ecuador (Acosta-Solis, 1959), and in the Pacific coast of Colombia (Lamb, 1959). Another area of intense dynamism and mangrove development is found along the coasts of Suriname, French Guiana and the northern part of Brazil, north of the mouth of the Amazon. Extraordinarily well developed black mangrove (Avicennia) forests are typical of this coast. Stands reach $30 \mathrm{~m}$ in height and diameters of $50-70 \mathrm{~cm}$ are common at the island of Maracá, about 2 degrees north of the equator (Schaeffer-Novelli et al., 1988). Interestingly enough, mangrove development and coverage near the delta of the Amazon river is restricted because of the overwhelming fresh water discharge and intense tidal and wave energies.

The belt of greatest mangrove development is roughly restricted to within 10 degrees of the equator except on the Pacific coast of South America, where the cold Humbold Current suppresses convective activity and creates extremely desertic conditions. The terminus of mangrove forests on this coast lies at the mouth of the Tumbes river barely $03^{\circ} 48^{\prime}$ south of the equator. Isolated mangroves occur further south (to about $5^{\circ} 30^{\prime} \mathrm{S}$ ) but conditions along the remainder of this barren coast are not conductive to mangrove establishment or development. On the Atlantic side, on the other hand, mangroves develop as far as $28^{\circ} 30^{\prime} \mathrm{S}$ along the Brazilian coast, where they eventually become limited by low temperatures and sporadic frost events. Mature red mangroves at their latitudinal Southern limit barely reach 1 meter tall, but black mangroves still reach more than 8 meters in height at Laguna $\left(28^{\circ} 30^{\prime} \mathrm{S}\right)$. In fact the landscape here is dominated by herbaceous vegetation (Spartina) with scattered and isolated white mangrove (Laguncularia) clumps.

On the Latin America northern hemisphere mangroves reach $31^{\circ} \mathrm{N}$ near Puerto Lobos, Gulf of California. On the Gulf coast of Florida they reach $30^{\circ} 24^{\prime} \mathrm{N}$, whereas on the Atlantic coast they reach $29^{\circ} 54^{\prime} \mathrm{N}$, and on the Bermuda island they occur at $32^{\circ} \mathrm{N}$.

\section{Mangrove research in Latin America}

We can divide the study of Latin American mangroves into three stages: an early phase consisting of the narratives of the first visitors to the region (Oviedo, 1526; Souza, 1971) and others, followed by the more detailed observations of well known naturalists from the latter part of the $19^{\text {th }}$ and early $20^{\text {th }}$ centuries such as Eggers (1892), Schimper (1903) and others who provided the first detailed scientific accounts of mangrove systems in the New World. Finally, in this century we find more detailed local studies such as the description of the mangroves of Santos by Luederwaldt (1919), and Cananéia (Gerlach, 1958) in Brazil, the description of the mangroves of the Pacific coast of Colombia by West (1956), the review of mangrove biology by Cuatrecasas (1958), the description of Ecuadorian mangroves by Acosta-Solis (1959) and the ecophysiological studies of Pannier $(1959,1962)$, Pannier \& Rodriguez (1967) in Venezuela, and in Brazil by Lamberti (1969). Thom (1967), in his studies of the mangroves of the Tabasco delta (Mexico), stressed the importance of physiography and impinging geomorphic processes on the development of mangrove communities.

In the 1970 's, events related to the developing environmental movement in the United States and research by Heald (1969) and Odum (1970) pointing out the ecological role of mangroves as sources of organic matter to estuarine food webs, led to a marked interest in these systems, their ecology and management. Lugo, Snedaker and associates produced many important papers related to ecology, productivity, decomposition and transport of detritus, papers too numerous to cite here but well known to mangrove researchers everywhere. 
Noteworthy, however, is the review on the ecology of mangroves by Lugo \& Snedaker (1974). Pool et al. (1977) made the first comparative structural study of mangrove forests in Florida, Puerto Rico, Mexico and Costa Rica. This interest quickly trickled to the South American region, mainly through the efforts of the UNESCO Regional Office in Latin America (ROSTLAC), which, recognizing the importance of mangrove research and conservation in the area, sponsored in December 1978 a Symposium on the Scientific Aspects and Human Impact on the Mangrove Ecosystem. Thirty one papers were presented in this important symposium (UNESCO/ROSTLAC, 1980). UNESCO/ROSTLAC also sponsored the publication of an introduction to mangrove ecology (Cintron \& Schaeffer-Novelli, 1983). This publication is in the Spanish language and is directed to students and resource managers in Latin America.

It appeared for a while that the recognition of mangroves as valuable resources would result in the sponsorship of vigorous research and the development of plans for sustainable and multiple use of mangrove forest resources. This would have contributed to the rational use of a historically abused and poorly understood resource. Unfortunately this was not to be. The economic recession of the 80 's and its impact on funding agencies, both national and international, and changing national priorities have dramatically curtailed scientific research. The lack of external funding has also prevented regional coordination and as a result most of South and Central American countries lack active ongoing research on their mangrove forests. Research throughout the region lacks cohesiveness and coordination.

\section{Current research}

Research in the regions is now almost totally supported by local governments and educational institutions. Probably the most active research centers are the National Autonomous University of Mexico (UNAM), and the University of Sāo Paulo (Brazil). In 1981 the United Nations Development Programme (UNDP) sponsored a project for the characterization of the mangroves of Venezuela and Trinidad. This project, carried out by the Ministry of the Environment and Natural Resources in Venezuela, has been completed but remains unpublished. In Trinidad, Ramcharan et al. (1982) prepared an inventory of the coastal wetlands of Trinidad and Tobago. The need for the integrated management of coastal systems in the Caribbean let do the organization in 1982 of a workshop on the interactions between coral reefs, seagrass beds and mangroves (UNESCO, 1983a). Among the recommendations of this workshop is that research efforts must involve the region's scientific resources and must have as one of its goals the strengthening of its scientific and management capability. More recently (1984), the Organization of American States supported a regional study in which Brazil, Suriname, Colombia, Mexico, and the Dominican Republic participated. As part of this project a training course was held in Puerto Rico in 1986. However, budget cuts in the OAS dramatically curtailed the original scope of this project and its most important objectives will remain unattained. In support of this regional study, Cintron \& Schaeffer-Novelli (1985) reviewed the available structural data for mangroves and described patterns in stand development and relationships between structural and functional characteristics. For the workshop held in Puerto Rico a mangrove methods manual was prepared (Schaeffer-Novelli \& Cintron, 1986) for the uniform description of structural parameters in the regional study. This manual is an enlarged version of a chapter previously included in the UNESCO manual on mangrove methodology (Cintron \& Schaeffer-Novelli, in UNESCO, 1984).

Mangrove systems are complex. Although many studies are available we still do not understand many basic processes, responses and restoration mechanisms. Mangrove projects ${ }^{\circ}$ in the region must adopt a system level approach duly recognizing that ecosystem problems are interdisciplinary and require integration. Long-term studies must be initiated to assess natural and man induced changes as well. These studies will require intra and inter institutional linkages and close cooperation among researchers in the region. Certainly some regional mechanism will be needed to provide coordination and avoid duplication of efforts. The UNESCO/COMAR/COSALC project may be an instrument to reach this goal if funding is made available and can be directed to mangrove studies as recommended by the Research and Training Group (RTG) at the COSALC project meeting of November 1982 in Venezuela (UNESCO, 1983b). Similarly; national centers for coordination will be required. In the report of the seminar organized in Cali, Lugo (in UNESCO, 1979) suggested the elements of a regional project for research in Latin American mangroves. His recommendations are still valid and should be given serious consideration.

\section{Strategy for action}

The alarming rate at which mangroves are being destroyed in the region requires that prompt actions be taken to develop a regional program such as the one recommended in the UNESCO Cali meeting, capable of fostering and supporting ecosystemic research, the development and compilation of management guidelines and the training of scientific personnel, resource managers, and providing for public environmental education. The great malleability and accomodation to site factors exhibited by mangroves creates a requirement for management strategies that are site specific. These guidelines and strategies for effective management of a complex resource can only be developed through research, and only through research can we hope to learn to conserve these valuable coastal resources.

\section{Resumo}

Os manguezais do Novo Mundo são bem menos ricos em espécies vegetais que os do Velho Mundo. Entretanto, essa simplicidade é apenas aparente, pois as espécies de mangue são extraordinariamente maleáveis quanto às suas adaptaçōes ao ambiente. Geograficamente, os manguezais atingẹm seu máximo desenvolvimento 
estrutural onde os subsídios das precipitaçōes pluviais e das marés são maiores. Essas condiçōes ocorrem na costa NW do Continente Americano e da porção oriental do litoral da Venezuela (Golfo de Paria) até São Luís, no Maranhão (Brasil).

$\mathrm{O}$ interesse pelo estudo e manejo do ecossistema manguezal ocorrido na década de 1970 , destacou a função ecológica do sistema como fonte de matéria orgânica para a cadeia alimentar estuarina.

A recessão dos anos 80 marcou uma dramática redução dos fundos para pesquisa, tanto nacionais como internacionais. Atualmente os projetos de pesquisa sāo sustentados, praticamente, por recursos institucionais locais.

As elevadas taxas de destruição dos manguezais na regiāo exigem ações decisivas dos órgãos competentes, incluindo apoio à pesquisa, desenvolvimento de planos de manejo e formação de recursos humanos, além da organização de programas de educação ambiental. Essas metas somente serão atingidas através de projetos de pesquisa bem estruturados.

\section{References}

ACOSTA-SOLIS, M. 1959. Los manglares del Ecuador. Contrnes Inst. ecuat. Cienc. natur., (59):1-82.

CINTRON, G. \& SCHAEFFER-NOVELLI, Y. 1983. Introducción a la ecología del manglar. Montevideo, UNESCO/ROSTLAC. 109 p.

$\&$

1985.

Caracteristicas y desarrollo estructural de los manglares de Norte y Sur America. Ciencia interamer., 25(1/4):1-15.

CUATRECASAS, J. 1958. Introducción al estudio de los manglares. Boln Soc. Bot. Méx., 23:84-98.

DAVIES, J. L. 1964. A morphogenic approach to world shorelines. Z. Geomorph., 8(Mortensen Sonderheft):127-142.

EGGERS, H. von. 1892. Die Manglares in Ecuador. Bot. Zbl., 52(2):49-52.

GERLACH, S. A. 1958. Die Mangroveregion tropischer Küsten als Lebensraum. Z. Morph. Ökol. Tiere., 46:636-730.

HEALD, E. J. 1969. The production of organic detritus in a south Florida estuary. PhD. Dissertation. University of Miami. 110p.

LAMB, F. B. 1959. The coastal swamp forest Nariño, Colombia. Caribb. Forester, 20:79-89.

LAMBERTI, A. 1969. Contribuição ao conhecimento da ecologia das plantas do manguezal de Itanhaém. Bolm Fac. Filos. Ciênc. Univ. S Paulo, (317), Bot. (33):1-317.
LUEDERWALDT, H. 1919. Os manguezaes de Santos. Revta Mus. paul., 11:309-408.

LUGO, A. E. \& SNEDAKER, S. C. 1974. The ecology of mangroves. A. Rev. Ecol. Syst., 5:39-64.

ODUM, W. E. 1970. Pathways of energy flow in a south Florida estuary. PhD. Dissertation. University of Miami. $162 \mathrm{p}$.

OVIEDO, G. F. 1526. Historia general y natural de las indias, islas y tierra firme del mar oceano. Biblioteca de autores españoles. Madrid, 1959. 7v.

PANNIER, F. P. 1959. El efecto de distintas concentraciones salinas sobre el desarrollo de Rhizophora mangle L. Acta cient. venez., Bot., 10:68-78.

1962. Estudio fisiologico sobre la viviparia de Rhizophora mangle. L. Acta cient. venez., Bot. 13:184-197.

\& RODRIGUEZ, P. 1967 . The B-complex inhibitor and its relation to vivipary in Rhizophora mangle L. Int. Revue ges. Hydrobiol., 52(5):783-792.

POOL, D. J.; SNEDAKER, S. C. \& LUGO, A. E. 1977. Structure of mangrove forests in Florida, Puerto Rico, Mexico and Costa Rica. Biotropica, 9:195-212.

RAMCHARAN, E. K.; SOUZA, G. DE \& FFRENCH, R. 1982. Inventory of the living resources of coastal wetlands in Trinidad and Tobago. Report, parts I and II. Natural Resources Programme. Chaguaramas, Institute of Marine Affairs. 13p.; 58p.

SCHAEFFER-NOVELLI, Y. \& CINTRON, G. 1986. Guia para estudo de áreas de manguezal; estrutura, função e flora. São Paulo, Caribbean Ecological Research. 150 p. + Apêndice.

; SOUZA,

M. L. D'R. \& FALKENBERG, D. de B. 1988. Expedição nacional aos manguezais do Amapá: Ilha de Maracá. Relatório técnico ao Conselho Nacional de Desenvolvimento Científico e Tecnológico CNPq. Linhas de Ação em Botânica, Ecossistema Manguezal. 99 p.

SCHIMPER, A. F. W. 1903. Plant geography on a physiological basis. Oxford, Oxford University Press. 839 p.

SOUZA, G. S. de. 1971. Tratado descriptivo do Brasil em 1527. Edição castigada pelo estudo e exame de muitos codice manuscritos existentes no Brasil, em Portugal, Espanha e França, e acrescentada de alguns comentários por F. A. de Vernhagem. São Paulo, Editora Nacional/EDUSP. 389 p. 
THOM, B. G. 1967. Mangrove ecology and deltaic geomorphology: Tabasco, Mexico. J. Ecol., 55:301343.

UNESCO. 1979. The mangrove ecosystem: scientific aspects and human impact. Report of the seminar organized by UNESCO at Cali, Colombia, 27 November-1 December 1978. UNESCO Repts mar. Sci., (9):1-40.

1983a. Coral reefs, seagrass beds and mangroves: their interactions in the coastal zones of the Caribbean. Report of a workshop held at West Indies Laboratory, St. Croix, U.S. Virgin Islands, May 1982. UNESCO Repts mar. Sci., (23):1-133.

1983b. Coastal ecosystems of Latin America and the Caribbean. Objectives, priorities and activities of UNESCO's COMAR project for the Latin American and Caribbean region. Caracas, Venezuela, 15-19 November 1982. UNESCO Repts mar. Sci., (24):1-46.
UNESCO. 1984. The mangrove ecosystem: research methods. Monogr. oceanogr. Methodol., U.N., (8):1-251.

UNESCO/ROSTLAC. 1980. Memorias del Seminario sobre el Estudio Científico e Impacto Humano en el Ecosystema de Manglares. Montevideo, UNESCO/ROSTLAC. 405p.

WEST, R. C. 1956. Mangrove swamps of the Pacific coast of Colombia. Ann. Ass. Amer. Geogr. 46:98-121. 